\title{
Penentuan Harga Opsi Barrier Menggunakan Metode Trinomial Kamrad- Ritchken Dengan Volatilitas Model Garch
}

\author{
S.Sulastri ${ }^{1}$, Lienda Novieyanti ${ }^{2}$, Sukono ${ }^{3}$ \\ Program Studi Kewirausahaan, Universitas Pendidikan Indonesia, Tasikmalaya, Indonesia \\ Departemen Statistika, Fakultas Matematika dan IImu Pengetahuan Alam, Universitas Padjajaran, Bandung, Indonesia ${ }^{2}$ \\ Departemen Matematika, Fakultas Matematika dan IImu Pengetahuan Alam, Universitas Padjajaran, Bandung, Indonesia ${ }^{3}$
}

\begin{abstract}
This study aims to minimize the violation of the assumptions of determining price options by taking into account the actual market conditions in order to obtain the right price that will provide high profits for investors. The method used to determine the option price in this study is the Kamrad Ritchken trinomial with volatility values that will be modeled first using GARCH. The data used in this study is daily data (5 working days per week) from the closing price of the stock price of PT. Bank Rakyat Indonesia, Tbk (BBRI. Based on the results of the research, the best model is GARCH (1,1). For the call up barrier option, increase the strike price with the initial price and barrier which causes the option price to call up the barrier "in" and "out" decreases, on the contrary to the put barrier option, an increase in strike price with the initial price and a barrier that causes the put barrier option price to both put up-in and put up-out. initial and barrier which still causes the call down barrier option price both in and out decreases, on the contrary in the put down barrier option, increasing strike price with the initial price and barrier which causes the put down barrier option price to increase in and out.
\end{abstract}

Keywords: Barrier Options, Trinomial, Kamrad Ritchken, Volatility, GARCH

\begin{abstract}
Abstrak. Penelitian ini bertujuan untuk meminimalkan pelanggaran asumsi-asumsi penentuan harga opsi dengan memperhatikan kondisi pasar yang sebenarnya sehingga diperoleh harga yang tepat yang akan memberikan keuntungan tinggi bagi investor. Metode yang digunakan untuk menentukan harga opsi dalam penelitian ini adalah trinomial Kamrad Ritchken dengan nilai volatilitas yang akan dimodelkan terlebih dahulu dengan menggunakan GARCH. Data yang digunakan dalam penelitian ini adalah data harian (5 hari kerja per minggu) dari harga penutupan harga saham PT. Bank Rakyat Indonesia, Tbk (BBRI). Berdasarkan hasil penelitian diperoleh model yang paling baik adalah GARCH (1,1). Untuk opsi call up barrier, peningkatan strike price dengan harga awal dan barrier yang tetap menyebabkan harga opsi call up barrier baik "in" maupun "out" menurun, sebaliknya pada opsi put barrier, peningkatan strike price dengan harga awal dan barrier yang tetap menyebabkan harga opsi put barrier baik put up-in maupun put up-out meningkat. Sedangkan untuk opsi call barrier, peningkatan strike price dengan harga awal dan barrier yang tetap menyebabkan harga opsi call down barrier baik in maupun out menurun, sebaliknya pada opsi put down barrier, peningkatan strike price dengan harga awal dan barrier yang tetap menyebabkan harga opsi put down barrier baik in maupun out meningkat.
\end{abstract}

Kata Kunci : Opsi Barrier, Trinomial, Kamrad Ritchken, Volatilitas, GARCH

Correspondence.sulastri@upi.edu, lienda@unpad.ac.id, sukono@unpad.ac.id

History of article. Received: Oktober 2018, Revision: Januari 2019, Published: Maret 2019

\section{PENDAHULUAN}

Opsi merupakan instrumen keuangan yang memegang peranan penting dalam suatu investasi. Seorang investor yang ingin melindungi investasinya dapat melakukan transaksi jual beli opsi. Di Indonesia, opsi mulai diperdagangkan pada tanggal 20 November 2007 yang diperkenalkan dengan nama Kontrak Opsi Saham (KOS). Opsi merupakan kontrak perjanjian antara dua pihak yang memberikan hak kepada salah satu pihak saja, untuk menjual atau membeli aset pada harga yang telah disepakati sampai waktu jatuh tempo. Berdasarkan waktu penggunaan haknya, opsi terbagi menjadi opsi Eropa yaitu opsi yang hanya dapat di eksekusi (exercise) pada tanggal berakhirnya kontrak, dan opsi Amerika yaitu opsi yang dapat di eksekusi kapan saja sampai waktu jatuh tempo. Opsi Eropa dan opsi Amerika dikenal sebagai opsi standar. Opsi lain selain opsi standar yang melibatkan turunan lebih kompleks disebut dengan opsi eksotik. Salah satu jenis opsi eksotik yang paling terkenal adalah opsi barrier (barrier option). Opsi barrier merupakan suatu opsi dimana pergerakan harga dari asset yang mendasarinya dibatasi pada tingkat harga yang telah ditentukan (Haruman \& Hendrawan, 2009). 
Salah satu faktor penting yang harus diperhatikan dalam transaksi jual beli opsi adalah menentukan harga opsi agar keuntungan yang diperoleh bisa maksimal. Oleh karena itu pengetahuan mengenai penentuan harga opsi yang akurat sangat diperlukan dalam membuat dan memutuskan strategi perdagangannya.

Dalam menentukan harga opsi barrier, terdapat beberapa faktor yang perlu diperhatikan antara lain harga saham awal, strike price, waktu, volatilitas harga saham, tingkat suku bunga bebas risiko dan metode yang digunakan. Saat ini dalam penentuan harga opsi masih banyak terjadi pelanggaran asumsi terhadap faktor-faktor tersebut, salah satunya adalah volatilitas.

Volatilitas merupakan ukuran ketidakpastian dari pergerakan harga saham pada waktu yang akan datang. Semakin besar volatilitas, akan semakin besar pula kemungkinan harga aset dapat naik atau turun secara drastis. Dalam model keuangan konvensional, volatilitas diasumsikan bernilai konstan selama satu periode tertentu. Asumsi ini tidak sesuai dengan kenyataan bahwa besarnya volatilitas tidak pernah tetap. Menurut Ross (1995) perhitungan volatilitas dapat dilakukan dengan berbagai metode salah satunya dengan standard deviasi namun perhitungan dengan standard deviasi dinilai kurang memiliki akurasi yang tepat karena belum memperhitungkan varian residualyang tidak konstan sebagai implikasi dari volatilitas yang terjadi dalam suatu data series. Varian residual yang tidak konstan ini pada umumnya disebut juga sebagai kondisi heteroskedastisitas.

Untuk memperlihatkan volatilitas yang tidak konstan salah satunya dapat dilihat pada pergerakan harga saham PT. Bank Rakyat Indonesia, Tbk (BBRI). Saham PT. Bank Rakyat Indonesia, Tbk merupakan salah satu saham yang memiliki volatilitas tinggi, hal ini dapat dilihat dengan masuknya saham tersebut ke dalam daftar emiten LQ45.

Indeks LQ 45 adalah nilai kapitalisasi pasar dari 45 saham yang paling likuid dan memiliki nilai kapitalisasi yang besar. Indeks LQ 45, menggunakan 45 saham yang terpilih berdasarkan likuiditas perdagangan saham dan disesuaikan setiap enam bulan (setiap awal bulan Februari dan Agustus). Maka saham yang terdapat dalam indeks tersebut akan selalu berubah. Pergerakan harga saham PT. Bank Rakyat Indonesia Tbk dapat dilihat pada Gambar 1.1. Berdasarkan Gambar 1. dapat dilihat harga saham Bank Rakyat Indonesia, Tbk mempunyai volatilitas yang cenderung tinggi. Pada suatu ketika bisa terjadi kenaikan yang tajam, kemudian juga terjadi penurunan secara tajam pula. Hal tersebut menunjukkan volatilitas harga saham yang tinggi.

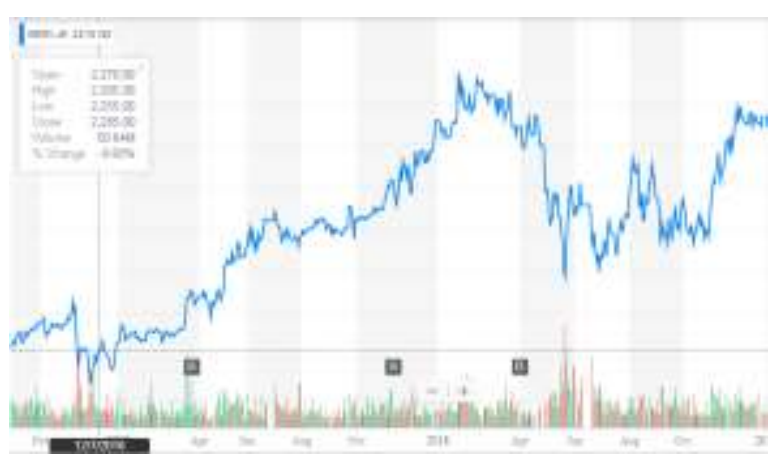

Sumber : finance.yahoo.com

Gambar 1. Harga Saham PT. Bank Rakyat Indonesia Tbk Periode Tahun 2016 - Januari 2019

Selain permasalahan volatilitas yang seringkali diasumsikan konstan, permasalahan dalam metode perhitungan harga opsi yang dipergunakan juga seringkali tidak sesuai dengan kondisi pasar. Contohnya dalam perhitungan harga opsi dengan menggunakan metode binomial, peluang pergerakan harga saham hanya dilihat naik atau turun saja. Padahal dalam kenyataannya harga saham tidak hanya mengalami kenaikan atau penurunan saja tetapi sangat memungkinkan pula harganya tetap.

Dalam menentukan harga opsi yang tepat maka kondisi-kondisi seperti di atas harus dapat diatasi. Dalam mengatasi permasalahan volatilitas dengan varian residual yang bersifat heteroskedastis pada tahun 1982 Engle memperkenalkan model Autoregressive Conditional Heteroscedasticity (ARCH). Engle menganalisis varian residual yang selalu berubah-ubah untuk setiap observasi dalam runtun waktu. Pada tahun 1986, Bollerslev mengembangkan model ARCH menjadi model GARCH (Generalized Autoregressive Conditional Heteroscedasticity). Menurut Bollerslev, varian residual tidak hanya bergantung pada residual periode lalu tetapi juga varian residual periode lalu. Dengan memodelkan terlebih dahulu varian residual dengan $\mathrm{GARCH}$ diharapkan diperoleh perhitungan volatilitas yang tepat sehingga nilai volatilitas ini dapat digunakan dalam perhitungan harga opsi.

Selain menentukan nilai volatilitas yang tepat, metode perhitungan harga opsi juga perlu memperhatikan kondisi pasar yang sebenarnya. Pada tahun 1979, Cox, Ross dan Rubinstein memperkenalkan modelbinomial. Pada model binomial, pemodelan pergerakan saham hanya memiliki dua kemungkinan yaitu naik atau turun sehingga dinilai memiliki kelemahan. Model ini dipandang tidak fleksibel dengan keadaan sebenarnya dimana kemungkinan pergerakan harga saham tidak hanya memiliki dua kemungkinan (naik atau turun) 
namun bisa saja harga saham tersebut tetap. Oleh karena itu Phelim Boyle (1986) mengembangkan suatu model yang dapat mengakomodasi adanya tiga kemungkinan pergerakan harga saham yang dikenal dengan model trinomial.

Model trinomial merupakan suatu pemodelan pergerakan harga saham yang mengasumsikan bahwa terdapat tiga kemungkinan pergerakan haga saham, yaitu naik, turun ataupun tetap. Karena jumlah titik kemungkinan harga sahamyang lebih banyak, model trinomial dianggap lebih akurat dan lebih cepat dalam penentuan harga opsi dibandingkan model binomial.

Tahun 1991, Ritchken memodifikasi model trinomial untuk penentuan harga opsi barrier karena model trinomial biasa yang dikembangkan oleh di nilai kurang efektif untuk digunakan dalam penentuan harga opsi barrier. Model trinomial Ritchken mencari nilai parameter stretch terbaik yang dapat menyesuaikan pohon harga saham sehingga barrier akan tepat terletak pada salah satu baris kemungkinan harga saham. Tesis ini akan membahas mengenai penentuan harga opsi barriermenggunakan metode trinomial ritchken dengan volatilitas model GARCH.

\section{METODE PENELITIAN}

Jenis penelitian yang digunakan merupakan jenis penelitian terapan. Data yang digunakan dalam penelitian ini adalah data sekunder yang diperoleh dari www.finance.yahoo.com berupa harga penutupan saham Bank Rakyat Indonesia (Persero) Tbk PT dengan kode BBRI. Langkah-langkah yang digunakan dalam penelitian ini yaitu sebagai berikut:

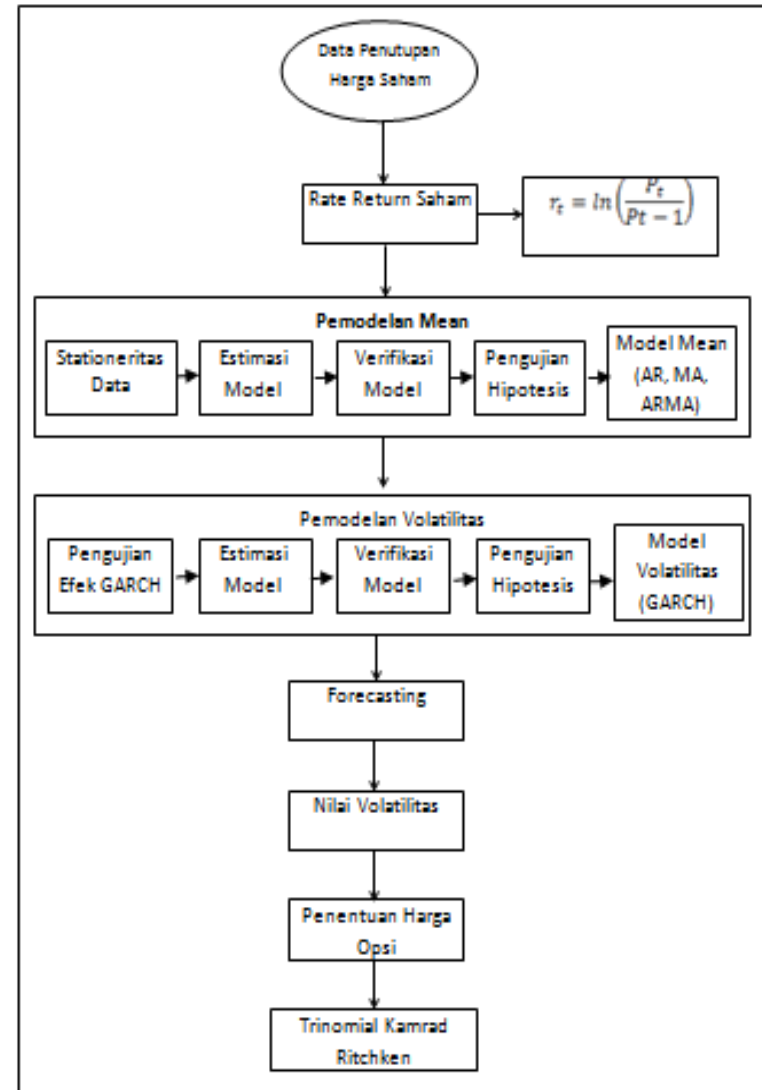

Gambar 2. Langkah Kerja Volatilitas Model GARCH

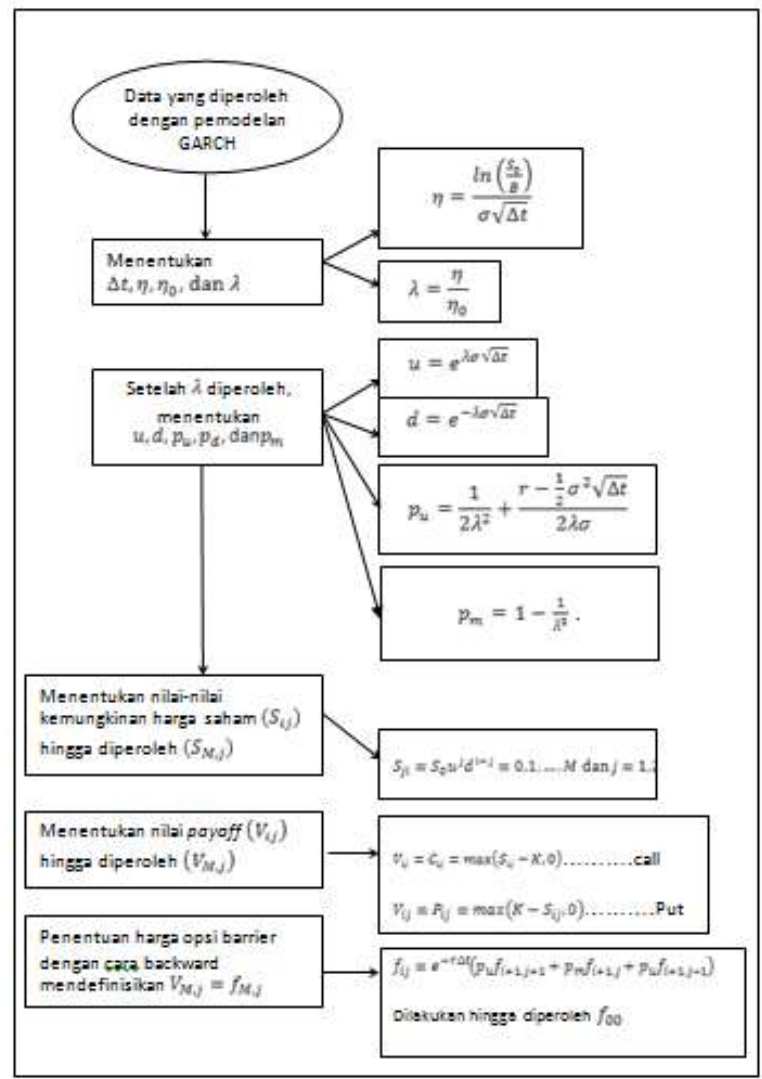

Gambar 3. Langkah Kerja Trinomial Kamrad Ritchken 


\section{HASIL DAN PEMBAHASAN}

Menentukan Volatilitas dengan GARCH

Pengujian Stationeritas Data

Identifikasi stationeritas data dapat dilihat melalui Gambar 4 berikut.

\begin{tabular}{l} 
Null Hypothesis: RETURW has a unit root \\
Exogenous: Constant, Linear Trend \\
Lag Length 0 (Automatic based on SIC, MAXAG=25) \\
\hline \hline \\
\hline
\end{tabular}

Gambar 4. Augmented Dickey Fuller Test (ADF Test)

Pengujian statsioneritas dengan menggunakan uji Augmented Dickey Fuller (ADF) dengan taraf signifikansi $\alpha=5 \%$, hipotesis sebagai berikut.

HO: Data tidak stationer

H1: Data stationer

Dengan kriteria uji yaitu tolak HO jika $|\mathrm{ADF}| \geq$ $\left|\mathrm{t}_{(\alpha, \mathrm{v})}\right|$ atau nilai Prob $<\alpha$. Berdasarkan hasil pengujian diperoleh nilai kritis t-statistic pada taraf signifikansi $5 \%$ nilai $|\mathrm{ADF}|=41,47356$ dengan nilai Prob $0,000<0,05$. Artinya HO ditolak atau data return saham stationer.

\subsubsection{Estimasi Mean Model}

Berdasarkan ciri teoritik proses $A R, M A$, atau ARMA maka identifikasi model AR, MA, atau ARMA dapat ditentukan dari ACF dan PACF nya. Berikut ini disajikan plot ACF dan PACF data return, seperti pada Gambar 5 dan 6.

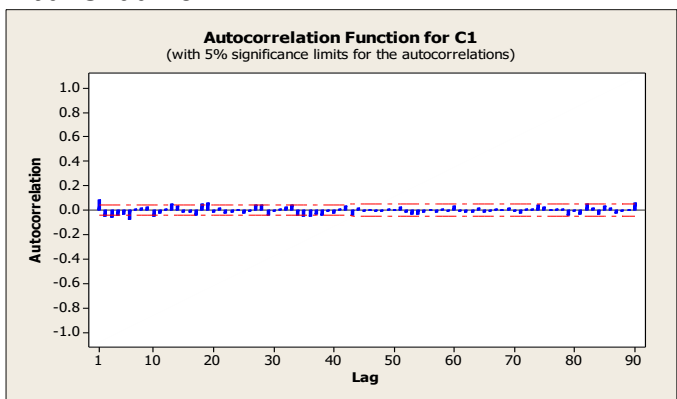

Gambar 5. ACF Data Return Saham PT. Bank Rakyat Indonesia

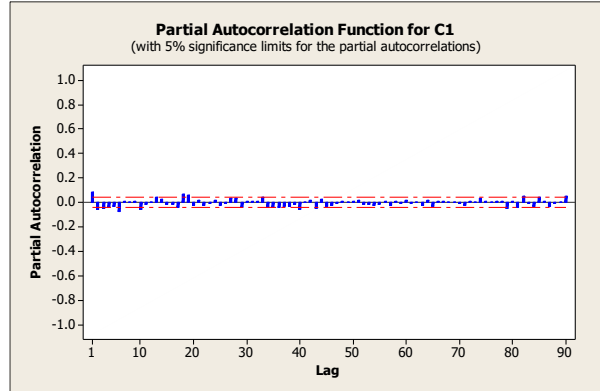

Gambar 6. PACF Data Return Saham PT. Bank Rakyat Indonesia

Berdasarkan Gambar 5 dan PACF pada Gambar 6 . terputus setelah lag ke-1, sehingga model yang mungkin adalah model AR (1), MA(1), dan ARMA(1,1). Setelah diperoleh beberapa model sementara, langkah selanjutnya adalah mencari penaksir terbaik untuk parameter model tersebut. Hasil penaksiran disajikan sebagai berikut. Berdasarkan beberapa model yang diusulkan tersebut, selanjutnya adalah dilakukan verifikasi model berdasarkan perbandingan AIC dan SC yang disajikan dalam Tabel 1.

Tabel 1. Nilai AIC dan SC Model AR(1), MA(1), dan $\operatorname{ARMA}(1,1)$

\begin{tabular}{ccc}
\hline Model & AIC & SC \\
\hline AR(1) & -4.353700 & -4.348170 \\
MA $(1)$ & -4.354917 & -4.349389 \\
ARMA $(1,1)$ & -4.354598 & -4.346302 \\
\hline
\end{tabular}

Penentuan model yang paling cocok dapat dilakukan berdasarkan nilai AIC dan SC. Model yang terbaik adalah model yang memiliki nilai AIC dan SC terkecil. Sehingga dari ketiga model di atas model terbaik yang dapat digunakan adalah model MA(1).

\subsubsection{Pengujian Hipotesis Model MA(1)}

Berdasarkan verifikasi model diperoleh model MA(1), selanjutnya akan dilakukan pengujian hipotesis pada model MA(1) yang meliputi uji parsial, uji simultan, dan pengujian diagnostik.

\section{Pengujian Parsial}

Berdasarkan verifikasi model dijelaskan bahwa kostanta pada model MA(1) tidak perlu diperhitungkan sehingga parameter yang diuji hanya untuk $\theta_{1}$ dimana hipotesis yang diajukan adalah.

$$
\begin{aligned}
& \text { HO : } \theta_{1}=0 \\
& \text { H1: } \theta_{1} \neq 0,
\end{aligned}
$$

kriteria uji tolak HOjika $\mathrm{t}>\mathrm{t}_{\alpha}$, dengan Prob $<\alpha$. Berdasarkan Tabel 2 diperoleh nilai $t=\frac{0.090961}{0.0221}=$ 
4.115355 dengan nilai Prob $0.000<0.05$ yang berarti HOditolak.

\section{Pengujian Simultan}

Berdasarkan verifikasi model dijelaskan bahwa kostanta pada model $\mathrm{MA}(1)$ tidak perlu diperhitungkan sehingga parameter yang diuji hanya untuk $\theta_{1}$ dimana hipotesis yang diajukan adalah.

$$
\begin{aligned}
& \mathrm{H} 0: \theta_{0}=\theta_{1}=\cdots=\theta_{\mathrm{n}}=0 \\
& \mathrm{H} 1: \exists \theta_{0} \neq \theta_{1} \neq \cdots \neq \theta_{\mathrm{n}} \neq 0,
\end{aligned}
$$

kriteria uji tolak $\mathrm{HO}$ jika $\mathrm{F}>\mathrm{F}_{\alpha}$, dengan prob $<\alpha$. Berdasarkan hasil pengujian diperoleh nilai $\mathrm{F}=$ 15.37191 dengan nilai Prob $0.000091<0.05$ yang berarti HO ditolak.

\section{Pengujian Diagnostik}

Hasil analisis di atas masih memerlukan pemeriksaan terhadap kenormalan data. Pemeriksaan kenormalan residu disajikan dalam Gambar 7 berikut ini.

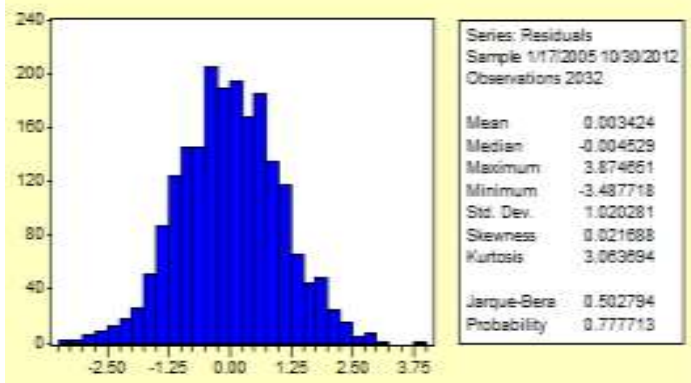

Gambar 7. Pengujian Normalitas Residual dari MA(1)

Pengujian normalitas data dilakukan dengan taraf signifikansi $\alpha=5 \%$, hipotesis sebagai berikut.

HO: Residualberdistribusi normal

$\mathrm{H} 1$ : Residualtidak berdistribusi normal

dengan kriteria uji yaitu tolak $\mathrm{HO}$ jika nilai Prob $<\alpha$. Berdasarkan Gambar 4.3dapat dilihat bahwa nilai Prob $0.777713>0,05$ sehingga HOditerima atau data berdistribusi normal.

Pengujian Efek Heteroskedastisitas

Berdasarkan estimasi mean model diperoleh model terbaik yaitu MA(1), maka sebelum memodelkan variansi residual dengan GARCH, terlebih dahulu akan diuji ada tidaknya efek heteroskedastisitas dalam residual dari model MA(1).

Tabel 2. ARCH LM Test

\begin{tabular}{llll}
\hline ARCH Test: & & & \\
\hline \hline F-statistic & 173.6094 & Probability & 0.000000 \\
Obs ${ }^{\star}$ R-squared & 160.0831 & Probability & 0.000000 \\
\hline \hline
\end{tabular}

Pengujian efek heteroskedastisitas dilakukan dengan menggunakan ARCH LM Test dengan taraf signifikansi $\alpha=5 \%$, hipotesis sebagai berikut.

$\mathrm{HO}$ : Tidak terdapat efek heteroskedastisitas

$\mathrm{H} 1$ : Terdapat efek heteroskedastisitas

dengan kriteria uji yaitu tolak $\mathrm{HO}$ jika $\mathrm{LM}>$ $\chi_{\mathrm{m}}^{2}(\alpha)$ atau nilai Prob $<0.05$. Berdasarkan Tabel 2 dapat dilihat bahwa nilai $\mathrm{LM}=160,0831$ dengan nilai Prob $0.000<0,05$ sehingga $\mathrm{HO}$ ditolak atau terdapat efek GARCH pada data.

Selain menggunakan LM Test, pengujian efek heteroskedastisitas juga dapat dilakukan dengan melihat correlogram Squared Residual sebagai berikut.

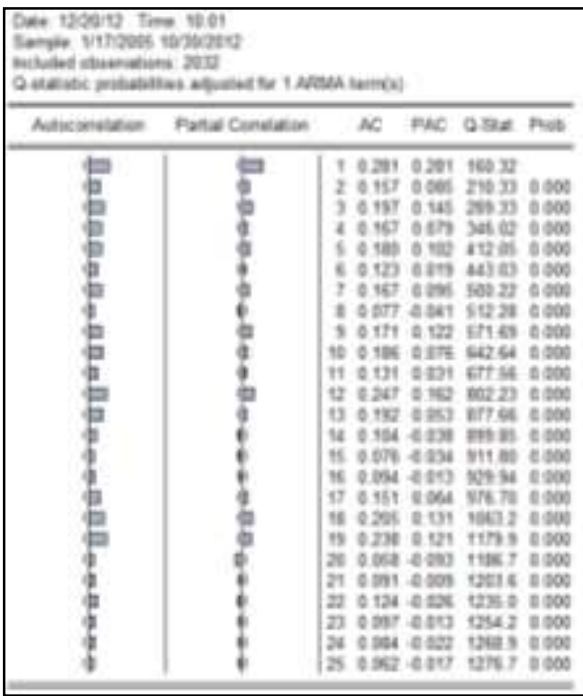

Gambar 8. Correlogram Squared Residual

Pengujian efek heteroskedastisitas dilakukan melalui Correlogram Squared Residual dengan taraf signifikansi $\alpha=5 \%$, hipotesis sebagai berikut.

HO: tidak terdapat efek heteroskedastisitas $\mathrm{H} 1$ : terdapat efek heteroskedastisitas dengan kriteria uji yaitu tolak HO jika nilai Prob $<\alpha$. Berdasarkan Gambar 8 dapat dilihat bahwa nilai Prob $0.000<0,05$ sehingga HO ditolak atau terdapat efek GARCH pada data.

\subsubsection{Estimasi dan Verifikasi Model GARCH}

Dalam mengidentifikasi model volatilitas GARCH dapat dilihat dalam correlogram pada Gambar 9, dalam gambar tersebut terlihat bahwa ACF dan PACF turun pada lag-1 sehingga model volatilitas sementara adalah $\operatorname{GARCH}(1,1)$ namun untuk mencari model yang terbaik akan diuji pula $\operatorname{GARCH}(1,2)$, $\operatorname{GARCH}(2,1)$ dan $\operatorname{GARCH}(2,2)$.Setelah memenuhi asumsi adanya efek heteroskedatisitas maka selanjutnya adalah identifikasi model kemudian mengestimasi parameter dari beberapa model yang diusulkan. Setelah dilakukan estimasi parameter model GARCH selanjutnya dilakukan uji diagnostik 
terhadap masing-masing model yang diajukan. Uji diagnostik dilakukan dengan cara uji keberartian koefisien serta membandingkan nilai AIC dan SC. Berdasarkan hasil pengujian bahwa hanya model GARCH $(1,1)$ yang memiliki nilai Prob $<0,05$. Dilihat dari nilai AIC dan AC juga model GARCH(1,1) memiliki nilai-nilai yang paling kecil yaitu AIC $=-4.559635$ dan nilai SC=-4.545814. Sehingga model terbaik yang akan digunakan untuk peramalan yaitu model $\operatorname{GARCH}(1,1)$.

Pengujian Hipotesis Model Volatilitas

Berdasarkan verifikasi model diperoleh model $\operatorname{GARCH}(1,1)$, selanjutnya akan dilakukan pengujian hipotesis pada model $\operatorname{GARCH}(1,1)$ yang meliputi uji parsial, uji simultan, pengujian diagnostik, dan pengujian heteroskedastisitas untuk $e_{t}$.

1. Pengujian Parsial

Pengujian secara parsial akan dilakukan terhadap model mean dan model volatilitas. Hipotesis yang diajukan adalah.

$$
\begin{aligned}
& \mathrm{H} 0: \alpha_{\mathrm{i}}=0 \\
& \mathrm{H} 1: \exists \alpha_{\mathrm{i}} \neq 0 \text {,dimana } \mathrm{i}=1,2,3,4,5
\end{aligned}
$$

Hasil pengujian hipotesis secara parsial disajikan dalam Tabel 3 berikut ini.

Tabel 3. Hasil Pengujian Parsial

\begin{tabular}{|c|c|c|c|}
\hline & Z & Prob & Keputusan \\
\hline Model Mean & \multicolumn{4}{|l|}{} \\
\hline$\alpha_{1}$ & 3.153024 & 0.000 & HOditolak \\
\hline$\alpha_{2}$ & 2.853813 & 0.000 & HOditolak \\
\hline \multicolumn{4}{|l|}{ Model Volatilitas } \\
\hline$\alpha_{3}$ & 4.822599 & 0.000 & HOditolak \\
\hline$\alpha_{4}$ & 8.541618 & 0.000 & HOditolak \\
\hline$\alpha_{5}$ & 75.49345 & 0.000 & HOditolak \\
\hline
\end{tabular}

kriteria uji tolak H0jika $\mathrm{z}>\mathrm{z}_{\alpha}$, dengan Prob $<\alpha$. Berdasarkan Tabel 3 dapat dilihat bahwa seluruh koefisien memiliki nilai Prob $0.000<0.5$ sehingga secara parsial HO untuk masing-masing koefisien di tolak.

\section{Pengujian Simultan}

Hipotesis yang diajukan dalam pengujian simultan adalah.

$$
\begin{aligned}
& \mathrm{H} 0: \alpha_{1}=\alpha_{1}=\cdots=\alpha_{5}=0 \\
& \mathrm{H} 1: \exists \alpha_{1} \neq \alpha_{1} \neq \cdots \neq \alpha_{5} \neq 0
\end{aligned}
$$

kriteria uji tolak $\mathrm{HO}$ jika $\mathrm{F}>\mathrm{F}_{\alpha}$, dengan Prob $<\alpha$. Berdasarkan Tabel 4 (Lampiran 2) diperoleh nilai $\mathrm{F}=$ 2.610432 dengan nilai Prob $0.033916<0.05$ yang berarti $\mathrm{HO}$ ditolak.

\section{Pengujian Diagnostik Model}

Hasil analisis di atas masih memerlukan pemeriksaan terhadap kenormalan data. Pemeriksaan kenormalan residu disajikan dalam Gambar 10 berikut ini.

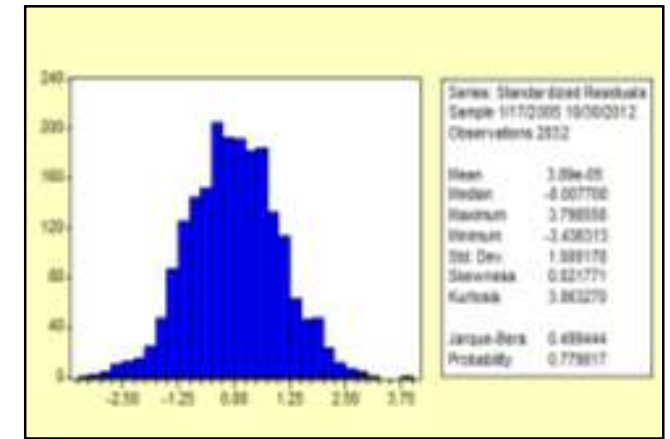

Gambar 9. Pengujian Normalitas Residual Model GARCH $(1,1)$

Pengujian normalitas data dilakukan dengan taraf signifikansi $\alpha=5 \%$, hipotesis sebagai berikut.

HO: Residual berdistribusi normal

$\mathrm{H} 1$ : Residualtidak berdistribusi normal dengan kriteria uji yaitu tolak $\mathrm{HO}$ jika nilai Prob $<0.05$. Berdasarkan Gambar 9 dapat dilihat bahwa nilai Prob $0.779017>0,05$ sehingga HO diterima atau data berdistribusi normal.

3. Pengujian Efek Heteroskedastisitas untuk $e_{t}$ Pengujian selanjutnya yang dilakukan untuk model GARCH ini adalah pengujian kembali efek GARCH dalam residual model. Hasil pengujian ditunjukkan pada Tabel 4.

Tabel 4. ARCH LM Test

\begin{tabular}{|llll}
\hline \hline F-statistic & 0.001107 & Probability & 0.973466 \\
Obs ${ }^{\star}$ R-squared & 0.001108 & Probability & 0.973450 \\
\hline \hline
\end{tabular}

Pengujian efek heteroskedastisitas pada data tersebut dilakukan dengan menggunakan ARCH LM Testdengan taraf signifikansi $\alpha=5 \%$, hipotesis sebagai berikut.

HO: Tidak terdapat efek heteroskedastisitas

$\mathrm{H} 1$ : Terdapat efek heteroskedastisitas dengan kriteria uji yaitu tolak HO jika LM > $\chi_{\mathrm{m}}^{2}(\alpha)$ atau nilai Prob<0.05. Berdasarkan Tabel 4.2 dapat dilihat bahwa nilai $\mathrm{LM}=0.001108$ dengan nilai Prob0.000 $>0,05$ sehingga H0diterima atau tidak terdapat efek GARCH pada data.

Selain dengan menggunakan LM Test, pengujian efek heteroskedastisitas juga dapat dilakukan dengan melihat correlogram Squared Residual sebagai berikut. 


\begin{tabular}{|c|c|c|c|c|c|}
\hline Autocorrelation & Partial Correlation & $A C$ & PAC & Q-Stat & Prob \\
\hline 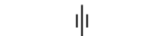 & 悄 & $1-0.001$ & -0.001 & 0.0008 & \\
\hline | & 悄 & 20.000 & 0.000 & 0.0011 & 0.974 \\
\hline 少 & 川 & 30.008 & 0.008 & 0.1392 & 0.933 \\
\hline$\|$ & $\|$ & $4-0.015$ & -0.015 & 0.6153 & 0.893 \\
\hline$\|$ & H & $5-0.020$ & -0.020 & 1.4303 & 0.839 \\
\hline$\|_{1}$ & 中 & 60.003 & 0.003 & 1.4505 & 0.919 \\
\hline d & di & $7-0.027$ & -0.027 & 2.9383 & 0.817 \\
\hline in & in & 80.015 & 0.015 & 3.4074 & 0.845 \\
\hline 中 & ip & 90.026 & 0.025 & 4.7617 & 0.783 \\
\hline 中 & 中 & $10 \quad 0.041$ & 0.041 & 8.1295 & 0.521 \\
\hline 巾 & 中 & $\begin{array}{ll}11 & 0.026\end{array}$ & 0.025 & 9.5187 & 0.484 \\
\hline 巾 & 1) & $12 \quad 0.029$ & 0.029 & 11.293 & 0.419 \\
\hline | & 中 & $13-0.008$ & -0.007 & 11.429 & 0.493 \\
\hline$\|$ & $\|$ & $14-0.024$ & -0.023 & 12.628 & 0.477 \\
\hline | & 中 & $15 \quad 0.005$ & 0.007 & 12.678 & 0.552 \\
\hline 中 & 忓 & $16-0.006$ & -0.003 & 12.757 & 0.621 \\
\hline$\|$ & $\|$ & $17-0.011$ & -0.008 & 13.000 & 0.673 \\
\hline 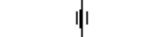 & $\|$ & $18-0.009$ & -0.011 & 13.161 & 0.725 \\
\hline$\|$ & $\|$ & $19-0.011$ & -0.013 & 13.399 & 0.767 \\
\hline il & 少 & $20 \quad 0.016$ & 0.012 & 13.905 & 0.789 \\
\hline \# & \# & $21-0.012$ & -0.017 & 14.222 & 0.819 \\
\hline di & q & $22-0.039$ & -0.041 & 17.323 & 0.691 \\
\hline 少 & 中 & $23 \quad 0.014$ & 0.012 & 17.698 & 0.724 \\
\hline$\|_{1}$ & 川 & $24 \quad 0.002$ & 0.003 & 17.708 & 0.773 \\
\hline$\|$ & $\|$ & $25-0.022$ & -0.020 & 18.680 & 0.769 \\
\hline
\end{tabular}

Gambar 10. Correlogram Squared Residual

Pengujian efek heteroskedastisitas dilakukan melalui Correlogram Squared Residual dengan taraf signifikansi $\alpha=5 \%$, hipotesis sebagai berikut.

HO: Tidak terdapat efek heteroskedastisitas

$\mathrm{H} 1$ : Terdapat efek heteroskedastisitas dengan kriteria uji yaitu tolak $\mathrm{HO}$ jika nilai Prob $<\alpha$. Berdasarkan Gambar 10 dapat dilihat bahwa nilai Prob $0.000>0,05$ sehingga H0diterima atau tidak terdapat efek GARCH pada data. Berdasarkan pengujian hipotesis tersebut dapat disimpulkan bahwa data sudah tidak mengandung efek heteroskedastisitas sehingga data sudah dapat digunakan peramalan.

\subsubsection{Peramalan}

Langkah terakhir dalam pembentukan model adalah melakukan peramalan satu langkah ke depan untuk memperoleh nilai volatilitas. Ramalan yang dilakukan adalah ramalan satu hari selanjutnya dari nilai penutupan harga saham PT. Bank Rakyat Indonesia dengan menggunakan model yang telah lolos uji diagnostik yaitu model GARCH(1,1).Berdasarkan hasil perhitungan (Lampiran 1) diperoleh nilai volatilitas adalah sebesar 0.0321atau sebesar $3.21 \%$.

\subsection{Menentukan Harga Opsi}

Tabel 5. Rekapitulasi Hasil PerhitunganHarga OpsiCall Up dan Put Up Barrier

\begin{tabular}{cccccccc}
\hline No & S0 & B & K & $\begin{array}{c}\text { Call } \\
\text { Up-In }\end{array}$ & $\begin{array}{c}\text { Call Up- } \\
\text { Out }\end{array}$ & $\begin{array}{c}\text { Put } \\
\text { Up- } \\
\text { In }\end{array}$ & $\begin{array}{c}\text { Put } \\
\text { Up- } \\
\text { Out }\end{array}$ \\
\hline 1 & 7400 & 7450 & 7000 & 194.2 & 221.48 & 0 & 0 \\
2 & 7400 & 7450 & 7050 & 174.24 & 192.01 & 0 & 0 \\
3 & 7400 & 7450 & 7100 & 154.28 & 162.55 & 0 & 0 \\
4 & 7400 & 7450 & 7150 & 134.32 & 133.08 & 0 & 0 \\
5 & 7400 & 7450 & 7200 & 114.35 & 103.61 & 0 & 0 \\
6 & 7400 & 7450 & 7250 & 94.39 & 74.23 & 0 & 0.09 \\
7 & 7400 & 7450 & 7300 & 74.43 & 45.61 & 0 & 0.95 \\
8 & 7400 & 7450 & 7350 & 54.47 & 20.34 & 0 & 5.14 \\
9 & 7400 & 7450 & 7400 & 34.51 & 3.55 & 0 & 17.83 \\
10 & 7400 & 7450 & 7450 & 14.55 & 0 & 0 & 43.75 \\
11 & 7400 & 7450 & 7500 & 3.79 & 0 & 9.34 & 73.22 \\
\hline
\end{tabular}

Berdasarkan tabel di atas dapat dilihat bahwa untuk opsi call up barrier, peningkatan strike price dengan harga awal dan barrier yang tetap menyebabkan harga opsi call up barrier baik in maupun out menurun. Namun begitu penurunan harga opsi pada call up-out lebih cepat dibandingkan pada call up-in. sebaliknya pada opsi put barrier, peningkatan strike price dengan harga awal dan barrier yang tetap menyebabkan harga opsi put barrier baik put up-in maupun put up-out meningkat. Namun begitu peningkatan harga opsi pada put upout lebih cepat dibandingkan pada put up-in. secara lebih jelas data disajikan dalam Gambar 11 sebagai berikut.

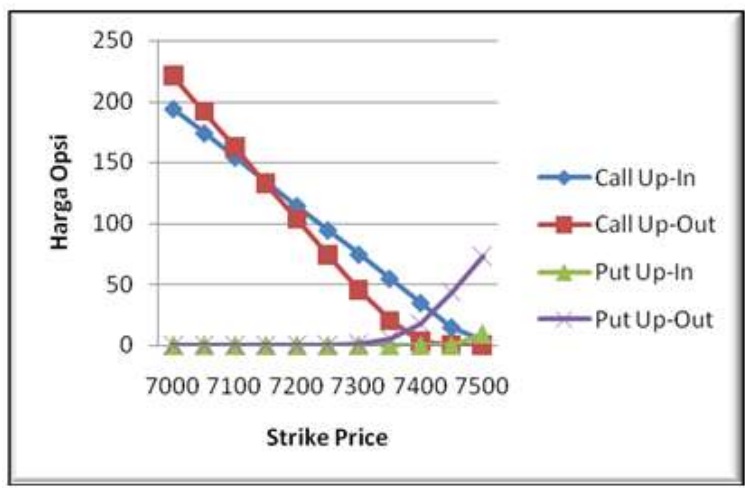

Gambar 11. Keterkaitan Strike Price dengan Harga Opsi Call dan Put Barrier

Sedangkan keterkaitan antara strike price dengan harga opsi call down dan put down disajikan dalam tabel berikut ini.

Tabel 6. Rekapitulasi Hasil Perhitungan Harga Opsi Call Down dan Put Down Barrier

\begin{tabular}{cccccccc}
\hline No & S0 & B & K & $\begin{array}{c}\text { Call } \\
\text { Down- } \\
\text { In }\end{array}$ & $\begin{array}{c}\text { Call } \\
\text { Down- } \\
\text { Out }\end{array}$ & $\begin{array}{c}\text { Put } \\
\text { Down- } \\
\text { In }\end{array}$ & $\begin{array}{c}\text { Put } \\
\text { Down- } \\
\text { Out }\end{array}$ \\
\hline 1 & 7400 & 7350 & 7000 & 63.88 & 357.14 & 0 & 0 \\
2 & 7400 & 7350 & 7050 & 54.02 & 317.03 & 0 & 0 \\
3 & 7400 & 7350 & 7100 & 44.16 & 276.92 & 0 & 0 \\
4 & 7400 & 7350 & 7150 & 34.3 & 236.81 & 0 & 0 \\
5 & 7400 & 7350 & 7200 & 24.44 & 196.7 & 0 & 0 \\
6 & 7400 & 7350 & 7250 & 14.67 & 156.59 & 0.09 & 0 \\
7 & 7400 & 7350 & 7300 & 5.66 & 116.48 & 0.94 & 0 \\
8 & 7400 & 7350 & 7350 & 0 & 76.37 & 5.14 & 0 \\
9 & 7400 & 7350 & 7400 & 0 & 39.13 & 15 & 2.87 \\
10 & 7400 & 7350 & 7450 & 0 & 15.14 & 24.86 & 18.99 \\
11 & 7400 & 7350 & 7500 & 0 & 4.02 & 34.72 & 47.98 \\
\hline
\end{tabular}

Berdasarkan Tabel 6 dapat dilihat bahwa untuk opsi call barrier, peningkatan strike price 
dengan harga awal dan barrier yang tetap menyebabkan harga opsi call down barrier baik in maupun out menurun. Namun begitu penurunan harga opsi pada call down-in lebih cepat dibandingkan pada call down-out. sebaliknya pada opsi put down barrier, peningkatan strike price dengan harga awal dan barrier yang tetap menyebabkan harga opsi put down barrier baik in maupun out meningkat. Namun begitu peningkatan harga opsi pada put down-inlebih cepat dibandingkan pada put down-out. secara lebih jelas data disajikan dalam Gambar 12 sebagai berikut.

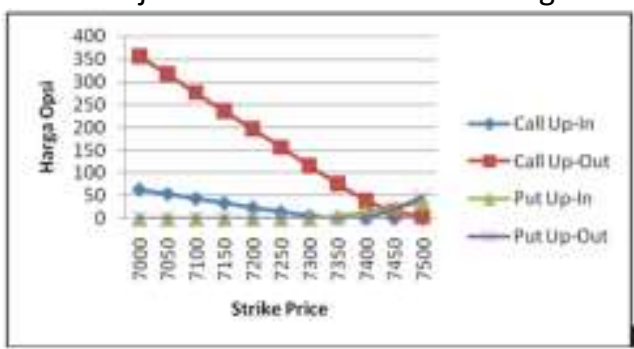

Gambar 12. Keterkaitan Strike Price dengan Harga Opsi Call Down dan Put DownBarrier

\section{KESIMPULAN}

Secara umum metode penentuan harga opsi barrier menggunakan trinomial Kamrad-Ritchken dengan volatilitas model GARCH adalah dengan memodelkan volatilitas terlebih dahulu berdasarkan pergerakan rate return harga saham, kemudian setelah dimodelkan baru dihitung nilai volatilitasnya. Berdasarkan pengolahan data pada BAB IV diperoleh bahwa pada kasus PT. Bank Rakyat Indonesia model GARCH yang paling baik adalah $\operatorname{GARCH}(1,1)$. Pada trinomial Kamrad Ritchken intinya adalah hitung kerenggangan pohon trinomial, kemudian hitung besar kenaikan dan penurunan harga saham beserta ketiga probabilitasnya. Selanjutnya bangun pohon harga saham dan hitung nilai payoffnya, kemudian hitung nilai opsi dengan cara backward (langkah mundur) hingga diperoleh nilai $f 00$.

Berdasarkan hasil simulasi, untuk opsi call up barrier, peningkatan strike price dengan harga awal dan barrier yang tetap menyebabkan harga opsi call up barrier baik in maupun out menurun, sebaliknya pada opsi put barrier, peningkatan strike price dengan harga awal dan barrier yang tetap menyebabkan harga opsi put barrier baik put up-in maupun put upout meningkat. Sedangkan untuk opsi call barrier, peningkatan strike price dengan harga awal dan barrier yang tetap menyebabkan harga opsi call down barrier baik in maupun out menurun, sebaliknya pada opsi put down barrier, peningkatan strike price dengan harga awal dan barrier yang tetap menyebabkan harga opsi put down barrier baik in maupun out meningkat.

\section{REKOMENDASI}

Penelitian ini membahas mengenai penentuan harga opsi dengan berbagai jenis barrier menggunakan model trinomial Kamrad-Ritchken dengan volatilitas model GARCH. Sebagai kajian lebih lanjut, dapat dipertimbangkan mengenai penentuan mean model. Dimana berdasarkan hasil pembentukan mean model perbedaan antara model $A R(1), M A(1)$, $\operatorname{ARMA}(1,1)$ tidak terlalu signifikan, sehingga pada penelitian selanjutnya dapat dipertimbangkan untuk membuat model GARCH dari mean model $A R(1)$ dan $\operatorname{ARMA}(1,1)$. Untuk perhitungan harga opsi trinomial Kamrad-Ritchken dapat dikaji lebih lanjut simulasi data dimana nilai barrier bergerak baik untuk barrier up maupun barrier down.

\section{DAFTAR PUSTAKA}

Abdul Halim,. 2003, Analisis Investasi, Edisi Pertama, Penerbit Salemba Empat : Jakarta

Black, Fischer and Myron S. Scholes, 1973, The Pricing of Options and Corporate Liabilities, Journal of Political Economy, 81 (3), 637-654, tersedia di http://www.cs.princeton.edu/courses/archive /fall09/cos323/papers/black_scholes73.pdf, diunduh tanggal 10 Agustus 2012

Bollerslev, T,1986, Generalized Autoregressive Conditional Heteroskedasticity, Journal of Econometrics, 31, 307-327. Tersediadi http://citeseer.ist.psu.edu/viewdoc/download ;jsessionid...?doi=10.1.1, diunduh tanggal 13 Agustus 2012

I. Brockwell, P.J and R. A. Davis, 1996, Introduction to Time Series and Forecasting, Second Edition, New York:Springer-Verlag,Inc

Enders, W, 2004, Applied Econometric Time Series. 2nd ed. New York: Wiley

Engle, R. F. and A. J. Patton,2001, What Good Is A Volatility Model?. Quantitative Finance 1, 237245.

Engle, R. F, 1982, Autoregressive Conditional Heterocedasticity $(\mathrm{ARCH})$ with Estimates of The Variance of United Kingdom Inflation.Journal of Econometrics 50, 987-1007. Tersedia di http://faculty.chicagobooth.edu/jeffrey.russell /teaching/finecon/readings/EngleARCH.pdf, diunduh tanggal 13 Agustus 2012

Halim, Abdul, 2003,Analisis Investasi, Jakarta: Salemba Empat.

John C. Cox, Stephen A. Ross, and Mark Rubinstein, 1979,Option Pricing: A Simplified Approach,Journal of Financial Economics 7: 
229-263.

Tersedia

di

http://www.er.ethz.ch/teaching/CoxRossRubi nstein_JFE1979.pdf, diunduh tanggal 13 Agustus 2012

John Hull and Alan White, 1990, Pricing Interest-Rate Derivative Securities, The Review of Financial Studies 1990 Volume 3, number 4, pp. 573-392, Tersedia http://efinance.org.cn/cn/feshuo/pricing\%20i nterest-rate-derivative\%20securities.pdf

Kamrad, B. and Ritchken, P, 1991, Multinomial Approximating Models For Options With $\mathrm{K}$ State Variables. Management Science, 37:1640-1652. Tersedia di http://mansci.journal.informs.org/content/37 /12/1640, diunduh tanggal 13 Agustus 2012

Kudret Topyan and Nusret Cakici, 2000, The GARCH Option Pricing Model:a Lattice Approach, Journal of Computational Finance, Volume 3, Number 4 Summer 2000, tersedia di http://www.risk.net/digital_assets/4413/v3n4 a4b.pdf, diunduh tanggal 13 Agustus 2012

McLeod, A.I., dan Li, W.K, 1983, Diagnostic Checking ARMA Time Series Models Using Squaredresidual Autocorrelations, Journal of Time Series Analysis, 4(4), 269-273. Tersedia di http://onlinelibrary.wiley.com/doi/10.1111/j. 1467-9892.1983.tb00373.x/, diunduh tanggal 5 Oktober 2012

Muhamad Nahdi, 2008, Perdagangan Derivatif : Menguntungkan atau Merugikan?, diunduh Tanggal 11 Agustus 2012 tersedia di http://muhamadnahdi.blogspot.com/2008/01 /artikel-perdagangan-derivatif.html

Nachrowi, Nachrowi D., dan Hardius Usman, 2006,Pendekatan Populer dan Praktis Ekonometrika Untuk Analisis Ekonomi dan Keuangan. Jakarta: Lembaga Penerbit Fakultas Ekonomi UI.

Nelson, D.B, 1991, Conditional Heteroscedasticity in Asset Return:A New Approach, Mimeo. University of Chicago. Graduate School of Business

Phelim Boyle, 1986,Option Valuation Using a ThreeJump Process, International Options Journal 3, 7-12.

Ross S. Guest and lan M. McDonald, 1995, The Volatility of The Socially Optimal Level Of Investment, Monash University, School of Banking and Finance

Ruppert, D, 2004,Statistics And Finance - An Introduction. Springer.

Soejoeti, Z, 1987, Analisis Runtun Waktu. Jakarta: Karunia Jakarta Universitas Terbuka.
Tendi Haruman dan Riko Hendrawan, 2009, Pengujian GARCH Option Model untuk Barrier Option di Bursa Efek Indonesia, Jurnal Keuangan dan Perbankan, Vol.13, No.2, Mei 2009, Hal 228236

Tsay, Ruey. S., 2005, Analysis of Financial Time Series. New Jersey: John Wiley\& Sons, Inc.

Wahyudi D. Maulana, 2010, Peramalan Nilai Tukar Rupiah terhadap Yen Menggunakan Model Volatilitas APARCH, Tugas Akhir Universitas Pendidikan Indonesia, Bandung ; tidak diterbitkan

Wei, W.W.S., 1990,Time Series Analysis, Univariate and Multivariate Methods, Canada, Addison Wesley Publishing Company.

Yue-Kuen Kwok, 2008, Mathematical Models of Financing Derivatives, Springer 